\title{
PROCEEDINGS
}

OF THE

\section{American Society of} International Law

AT ITS

SIXTY-FIRST ANNUAL MEETING

HELD AT

WASHINGTON, D. C.

APRIL 27-29, 1967

PUBLISHED BY THE SOCIETY 2223 Massachusetts Avenue, N.W.

WASHINGTON, D. C. 20008

1967 
CopYriant (C) 1967 BY

THE Amerioan Bociemy of International Law

It is the policy of the American Society of International Law not to take an official position, by resolution or otherwise, upon controversial questions. The views expressed in the addresses and remarks delivered at its annual meetings and appearing in its printed ProcrenINGs are those of the individual speakers and are not to be taken as representing the views of the Society. 


\section{TABLE OF CONTENTS}

OfFICERS AND CoMmitTEes For THE YEAR $1967-1968 \ldots \ldots \ldots \ldots \ldots$ vii

BoARd of REVIEW and DEVELOPMENT ................. ix

INCORPORATION ACT OF SEPTEMBER $20,1950 \ldots \ldots \ldots \ldots \ldots \ldots \ldots \ldots \ldots \ldots \ldots$

Resolution of ApRIL 28, $1951 \ldots \ldots \ldots \ldots \ldots \ldots \ldots \ldots \ldots \ldots \ldots$ xiv

Constitution of the American Society of International Law ... xv

Regulations of the Society $\ldots \ldots \ldots \ldots \ldots \ldots \ldots \ldots \ldots \ldots \ldots \ldots \ldots \ldots \ldots$

\section{First Session}

Thursday, AprIL 27, 1967, At 2:15 P.M.

Panel: International Law and Civil Wars-I

Address, "Non-Intervention and the Spanish Civil War," by Ann Van

Wynen Thomas and A.J. Thomas, Jr. ............... 2

Address, "The Algerian War of Independence," by Arnold Fraleigh 6

Address, "The Post-Independence War in the Congo," by Donald W.

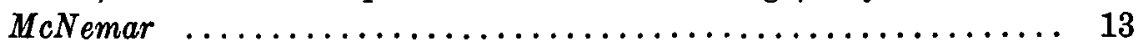

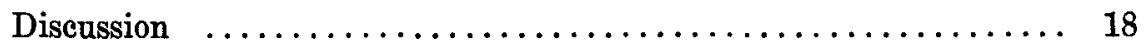

Reporter: Charles H. Gustafson

Panel: International Co-operation in Satellite Communications Srstems

Address, "International Co-operation in Satellite Communications Systems," by John A. Johnson ......................

Address, "International Co-operation in Telecommunication for Educational and Cultural Purposes," by Robert $K$. Woetzel .........

Address, "Domestic Communication Satellites and International Cooperation," by Lee R. Marks ..................... 36

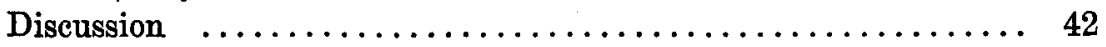

Reporter : Philip F. Patman

\section{Second Session}

ThURSDay, April 27, 1967, at 8:15 P.M.

Panel: Intrernational Law and Civil Wars-II

Address, "International Law and the American Civil War," by Quincy Wright .......................... 50

Address, "American Involvement in Latin American Civil Strife,"

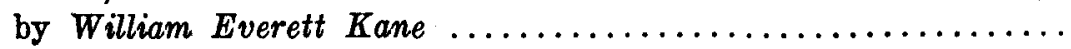
Address, "United States Involvement in Foreign Civil Strife since World War II," by Richard J. Barnet ................. 69 
Comments :

PAGE

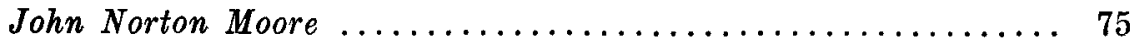

Abram Chayes ............................... 76

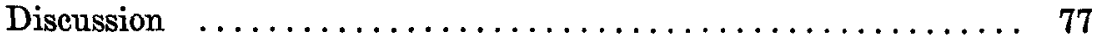

Reporter : Andrew H. Brenman

Panel: Concession Agreements-Problems and Trends in Negotiation and Renegotiation

(Joint Session with Section of International and Comparative Law, American Bar Association)

Address, "Long-Run Trends in Concession Contracts," by Raymond

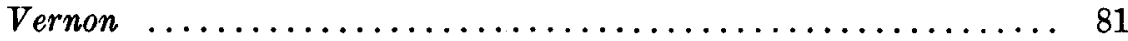

Address, "LAMCO: A Case Study of a Concession Contract," by

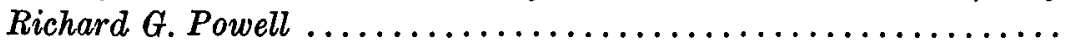

Address, "Diplomatic Intervention in Investment Disputes," by An-

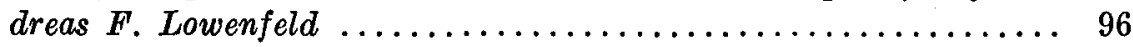

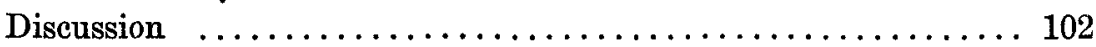

Reporter: D. Rudolph Henderson, Jr.

\section{Third Session}

Friday, April 28, 1967, at $9: 15$ A.m.

Panel: The People's Republic of China and International Law -Observations

Address, "Chinese Attitudes toward International Law-and Our Own," by Jerome A. Cohen . . . . . . . . . . . . . . . . 108

Address, "Certain Legal Aspects of Communist China's Treaty Practice," by Hungdah Chiu ..................... 117

Address, "Treaty Analysis and Communist China: Preliminary Observations," by Douglas M. Johnston ................ 126

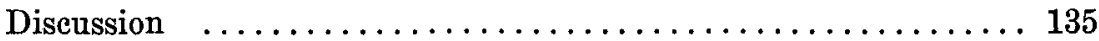

Reporter : Mark B. Feldman

Panel: Institutional Aspects of International Trade Address, "The GATT as an Instrument for Tariff Bargaining," by

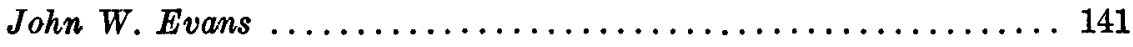

Address, "GATT as an Instrument for the Settlement of Trade Disputes," by John $H$. Jackson .................... 144

Address, "UNCTAD and GATT as Instruments for the Development of Trade Policy," by Joseph A. Greenwald .............. 155

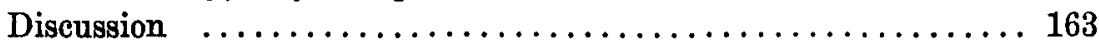

Reporter: Walter Hollis 


\section{Fourth Session}

Fridax, ApriL 28, 1967, at 2:15 P.M.

Panel: Institutional and Economic Perspectives on Latin American Integration

PAGE

Address, "Institutional Developments in Central American Integration," by $F . V$. Garcia-Amador ................... 167

Address, "Developments in the Latin American Free Trade Association," by Francisco Orrego-Vicuña .................. 174

Address, "Economic Aspects of Latin American Integration," by Walter J. Sedwitz ................................ 181

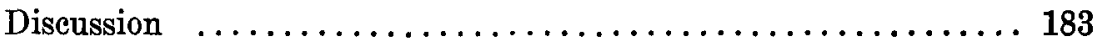

Reporter : Edison W. Dick

Panel: Some Contemporary Problems in Treaty Law Sugaested by the Draft articles on the Law of Treaties of the InTERNATIONAL LaW Commission

Address, "Stability and Change: Unilateral Denunciation or Suspension of Treaties by Reason of Changed Circumstances," by Oliver J. Lissitzyn ................................ 186

Address, "Breach of Treaty and Response Thereto," by Richard $B$.

Bilder

Comments by Myres $\boldsymbol{S}$. McDougal ....................204

Discussion .................................... 205

Reporter: Robert I. Starr

\section{Fifth Session}

Saturday, April 29, 1967, at 9:30 P.M.

\section{Business Meeting}

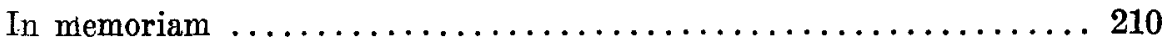

Report of Executive Vice President .................. 222

Reports of Committees :

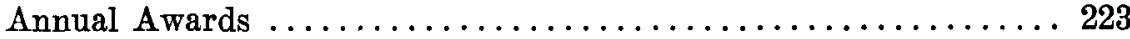

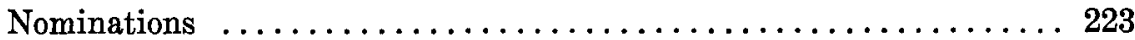

Publications of Department of State and United Nations ...... 224

Election of Officers ............................. 223

Members Emeriti .............................. 223

Saturday, April 29, 1967, at 2:15 P.M.

Philip C. Jessup International Law Moot Court Competition: Clatm of the United States Against France Arising out of Certain

INCIDENTS ON THE MOON

Judges: The Honorable Leonard C. Meeker, Legal Adviser of the Department of State; Charles N. Van Doren, Deputy General Counsel, U. S, 
Arms Control and Disarmament Agency; Walter D. Sohier, of the New York Bar; former General Counsel of the National Aeronautics and Space Administration

Finalists: Vanderbilt International Law Society $v$. Harvard International Law Club ................................ 225

\section{Annual Dinner \\ Friday, ApriL 28, 1966, at $7: 15$ P.M.}

PAGE

Remarks of the Toastmaster ...........226, 233, 239, 249, 251

Address by the President of the Society ................. 228

Address, "Making International Law in the United Nations," by Sir

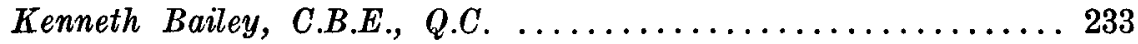

Address, "International Economic Relations and the Rule of Law," by

the Honorable Henry $H$. Fowler ................... 239

\section{Appendix}

Report of Committee on Department of State and United Nations

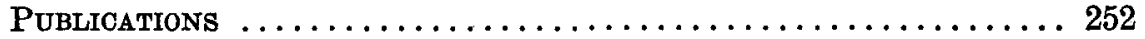

Report of Association of Student International Law Societies .. 265

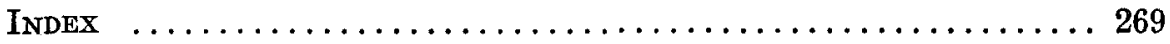

